\title{
Student intimidation, no pay and hunger strikes: the challenges facing Heads of Department in Bangladesh colleges
}

\author{
Mark T Gibson* \\ m.gibson@brookes.ac.uk \\ Oxford Brookes University
}

Mark Gibson is a Senior Lecturer at The School of Education, Oxford Brookes University, UK and was previously an Assistant Professor at the University of Nottingham Malaysia. His primary research and teaching are in the field of Educational Leadership and Management. His present research focuses on educational leadership in South East Asia and South Asia in both private and public sectors. He has published widely on educational leadership issues including international schools.

OrclD: 0000-0002-0761-0173 


\begin{abstract}
The role of the Head of Department is at the heart of tertiary education; it is where institutional policy and procedure is predominately enacted. The extant literature on the nature and challenges of such roles is almost exclusively from the Western world. The research that this article reports on examined the leadership and management structures and staff progression routes in Bangladesh colleges. The project then explored the roles and challenges facing Heads of Department in the colleges. Four focus groups were held comprising of a total of 26 Heads of Department from Bangladesh colleges. Findings indicate that the Bangladesh higher education system is highly centralised, from the Ministry of Education and the National University. Participants report their role as primarily paper-based administration with little autonomy. The challenges they face involve dealing with acute staffing shortages, student political activists and no preparation and development in the form of training. These roles and challenges differ from roles in higher education in the literature.
\end{abstract}

Key Words: higher education; middle leadership; head of department; Bangladesh college

\title{
Introduction
}

There has been an increase in the research literature in recent years on higher education leadership and management (Lumby, 2012) including the role of middle management (Black, 2015). Although there are a variety or post titles that can be considered as higher education middle management, ones that are below the position of Dean (Pepper \& Giles, 2015), such as Associate Dean, Sub Dean, Programme Director (Preston \& Price, 2012), Head of Department (Floyd \& Dimmock, 2011) and Head of School (Pepper \& Giles, 2015), the focus has frequently been on the Head of Department (Bryman, 2007). The department, for Bryman (2007), 'represents a crucial unit of analysis in universities, as it is often, if not invariably, a key administrative unit for the allocation of resources, and the chief springboard for the organization's main teaching and research activities' (Bryman, 2007 p.694). The leader of a department then becomes the focus for the implementation of university policy and practice. This article aims to contribute to the field by addressing the role of the Head of Department in Bangladesh tertiary colleges and the challenges they face.

Bangladesh's educational system is highly centralised with administrative powers being centred at the Ministry of Education in Dhaka (World Bank, 2013); this control exists across 
all sectors from primary to tertiary systems. The tertiary education system in Bangladesh is complex but essentially consists of three subsectors: universities; colleges (which are often affiliated to the National University); and technical and vocational institutions. There has been a period of rapid expansion of higher education in Bangladesh. There was a 60 per cent rise in institutions from 1748 to 2893 between 2010 and 2015, which was met mainly from the private sector (World Bank, 2017). The total number of students in tertiary education rose from 1.6 to 2.84 million across the same period (World Bank, 2017). There are 130 universities in Bangladesh, 38 are public the other 92 are privately managed, however, most higher education students are enrolled in the colleges which are teaching-orientated institutions that offer pass, honours and master's degrees 1, 494 of which are private and 265 public (World Bank, 2017). Most colleges are affiliated to the National University, which instead of delivering programmes itself, 'designs nationally accepted common course curricula for its affiliates, conducts examination, monitors and supervises its affiliates' long and short terms activities' (Alam, Mishra, \& Shahjamal, 2014 p.286).

Concern has been expressed about the quality of education in the colleges, Alam et al (2014) refer to the standard of education as 'very disappointing' (Alam et al., 2014 p.300), whilst others have called for the National University to have major reform (Asian Development Bank, 2014).

There is an absence of reliable data and information on the college sub sector which is seen as a 'major impediment for drawing a clear picture' (World Bank, 2014). Academic work on the tertiary sector in Bangladesh concentrates on universities, even when the title refers to higher education in Bangladesh the work is often solely about universities when most higher education students are in the colleges (e.g. Ariful Haq Kabir, 2012; Arif Haq Kabir \& Greenwood, 2017; Monem \& Beniamin, 2010; Rabbani \& Chowdhury, 2014). There is little English language academic work on colleges, let alone their leadership and management; the work on such 
institutions is predominately in the form of policy statements and reports such as those generated by the World Bank (World Bank, 2013, 2014, 2017). Given these roles are pivotal to an increasing number of students, in a sector in which there is expressed concern, such work is timely.

The aim of this paper is to explore the role and challenges of Heads of Departments in Bangladesh colleges. Following the literature review, the empirical findings from four focus groups of Bangladesh college Heads of Department are discussed and finally some implications are explored within the conclusion. Hallinger \& Chen (2015) in their systematic review conclude that scholarship on educational leadership and management in Asia is in its early stages and it is hoped that this article can contribute to it.

There were four research questions that guided this project:

1. What is the leadership and management structure in Bangladesh colleges?

2. What are the leadership and management progression routes for academic staff in a Bangladesh college?

3. What is a Head of Department's role in a Bangladesh college?

4. What challenges do Heads of Department in a Bangladesh college face in their role?

\section{Literature Review}

This literature review explores the extant literature on heads of department roles in higher education and the challenges that they face followed by a contextual look at colleges in Bangladesh. 


\section{The challenges facing higher education Heads of Department}

The English language literature surrounding heads of department in higher education is almost exclusively Western, concentrating on the USA, the UK, Australia and New Zealand. The role of the head of department may vary across institutions but typically, it may include providing a sense of direction/ strategic vision, allocating staff teaching time/workload, acting as a role model, creating a positive and collegial work atmosphere and advancing the departments cause internally and externally of the institution (Bryman, 2007), mentoring individual staff, undertaking staff performance reviews and responsibility for staff development (Franken, Penney, \& Branson, 2015). However, it is also noted that the role is changing and increasingly becoming more complex (Floyd, 2012). This diversification in career paths and conceptualisation of what an academic career is, is mapped by Enders \& Musselin (2008). Reforms in Western higher education institutions, particularly at the beginning of this century, are seen as the consequence of New Public Management narratives (Bleiklie, Enders, Lepori, $\&$ Musselin, 2011). The result is a reconfiguration of academic power within governance and external networks and producing increasingly hierarchal institutions. This may well change the role and challenges facing a Head of Department.

Challenges that Heads of Department face include the amount of workload from the management role in addition to teaching and research, in particular as it is the latter two that academics came into universities to do (Floyd, 2012, 2016; Floyd \& Dimmock, 2011). There are further problems with the sense of professional identity of such staff (Floyd, 2012), problems associated with being 'caught in the middle' and dealing with the staff they lead and simultaneously with organisational goals (Clegg \& McAuley, 2005). The challenge of dealing with poor performing and / or difficult staff frequently appears as a major issue (Pepper \& Giles, 2015; Thornton, Walton, Wilson, \& Jones, 2018), this aspect of the role being described 
as 'time consuming and unpleasant' by one participant in Thornton et al.'s study (Thornton et al., 2018 p.215).

There has been some, limited, academic work investigating Heads of Department in higher education in Asia. Research studies have focused on heads of department within higher education institutions in Malaysia (Ibrahim, 2012; Tahir, Abdullah, Ali, \& Daud, 2014) and India (Crosthwaite, 2018), though these tend to focus on competencies and effectiveness as opposed to roles and challenges. One paper refers to quality assurance issues within leadership and management in a Bangladesh public university (Parvin, 2019).

\section{Higher Education in Bangladesh}

In their review of academic published work on educational leadership and management in Asia, Hallinger \& Chen (2015) note that the literature within the field has been dominated by English speaking, 'Western' societies and as a consequence we have limited knowledge of the practice of educational leadership and management in Asia. Their systematic review across an eighteenyear period until 2012, the search involves all sectors, with higher education being only 9.4 per cent of the output. The review did not find any work relating to leadership and management in Bangladesh. The remainder of this section will focus on publications by the World Bank (World Bank, 2013, 2014, 2017) and academic journals.

Higher education in Bangladesh is highly centralised. The Ministry of Education in Bangladesh has the overall responsibility for "formulating policy, strategic leadership, and preparing the national budget for public funding in higher education" (World Bank, 2013 p.8), whilst the University Grants Commission manages both public and private universities which, although autonomous, is technically under the Ministry of Education. The University Grants Commission is the 'leading regulatory body for higher education in the country' (World Bank, 2017 p.5). The universities have considerable academic and managerial freedom whilst the 
public colleges operate as 'typical government organisations bound with rigid administrative and financial regulations that are common to all government offices and are sternly governed by the central authority in Dhaka' (World Bank, 2014 p.3).

The National University is the largest university in Bangladesh and makes up some 80 per cent of the tertiary level student population (World Bank, 2014), it is an affiliating institution with the colleges providing the teaching of the National University courses. There are nearly 2000 affiliating colleges, about 92 percent of which are privately managed, over half of which receive government financial support (World Bank, 2013). The public affiliated colleges have virtually no autonomy, unlike their private counterparts (World Bank, 2017). The National University is responsible for the curriculum in both public and private colleges and for admission procedures across all colleges and determining their academic structure including the number of teachers and students they admit (World Bank, 2014 p. 28). Hiring and firing academic and non-academic staff, making posting and promotion decisions are all governmental decisions in public affiliated colleges (World Bank, 2017). The National University sets the curriculum for its affiliated colleges centrally through its Center for Curriculum Development and Evaluation; there is limited flexibility for the colleges resulting them being 'constrained in innovating and improving the quality of instruction independently' due to the administrative and management challenges at the Center which have inhibited stakeholder participation in any curricula revision' (World Bank, 2013 p.60).

There is a lack of autonomous governance for the colleges, Islam (2008) believes that the greatest challenge in Bangladesh higher education is establishing principles of good governance. 'Serious concerns' exist in the internal governance of many affiliated colleges with the impact of politically influential people on the management of colleges including the recruitment of teaching staff (World Bank, 2014 p.vii). Existing accountability and monitoring 
systems are described as 'weak and ineffective' (World Bank, 2014 p.vii) due to the complex structure of affiliation.

The colleges' relation with the government is also fiscal. About 82 per cent of the teachers are employed in private colleges of which approximately half receive government pay in the form of a Monthly Pay Order (World Bank, 2014); making the government the paymaster for most college teaching staff, irrespective of the institution in which they serve.

Post recruitment there is little, if any, opportunity for professional development. A picture is painted of poorly qualified staff and a lack of resources such as libraries and internet provision; assessment is made purely by written examinations (Alam et al., 2014). There is also evidence of low staff morale in the colleges (Arif, Rahman, Reza, \& Osman, 2013; Pronay, 2011). For some, the National University requires 'major reform' (Asian Development Bank, 2014 p.xiii).

Higher education in Bangladesh is a party-political arena with direct political influence on campuses (Hossain \& Mohammad, 2015), for Monem \& Beniamin (2010) the 'administration, the teachers and students body have all been thoroughly politicised' (Monem \& Beniamin, 2010 p.300). This extends from governance, to staff appointments (Transparency International Bangladesh, 2016) and to students. The politicisation of students can result in disruption of teaching, for example Monem \& Beniamen (2010) describe student noisy processions in corridors and strikes causing unscheduled suspension of classes.

In addressing quality assurance issues within a Bangladesh public university, Parvin (2019), points to limitations within the system and its prevailing culture which affect the leadership and management roles. Parvin (2019) mentions that for the 'head of department.... the 'leadership and 'management' in this system are more involved in administrative routine work' (p. 740), 'the only requirement for head/deanship is seniority' (p.746) and that 'Academic 
leadership is conceived by them [participants] as a mere administrative post' (p747). These descriptions in Bangladesh appear different to the West.

It is a challenge for policy makers to develop the quality of the education students receive in the affiliated colleges. The Bangladesh government has addressed these issues through policy documents from the University Grants Commission, the Strategic Plan for Higher Education 2006-2016 and the Strategic Plan for Higher Education in Bangladesh: 2017-2030. The Asian Development Bank (Asian Development Bank, 2014) believes the former reflects a deep concern about the National University and its affiliated colleges, whilst the latter document, according to the World Bank (2017), is solely in reference to the university sub sector with the challenge for developing the colleges being addressed through the College Education Development Project, a World Bank 130 million USD funded project. The development objectives of the Project are:

to strengthen the strategic planning and management capacity of the college education subsector and to improve the teaching and learning environment of participating colleges. 1) The first component, Strengthening Strategic Planning and Management Capacity, aims to address planning, governance, and management challenges at the subsector level. It has two subcomponents as follows: (i) Development of a Strategic Plan for the College Subsector; and (ii) Improvement of the Teacher Management System (World Bank 2016).

Management is frequently referenced in these documents, the management of the whole subsystem for example is described as 'deficient' (World Bank, 2014 p.vii). However, the term 'management' in these documents is frequently referring to centralist organisations such as the National University. This literature helps us to appreciate macro contextual policy workings, however, it does little to assist us to understand the leadership and management at a micro level; of the individual colleges themselves. There appears to be little, if any, English language literature that refers to the leadership and management within Bangladesh colleges.

\section{Methods}


This qualitative study used a method of focus groups to elicit data. Focus groups are group discussions that are organised around specific issues which the participants are 'focused' upon and they differ from group interviews in that the key element is the interaction between the participants (Kitzinger, 1994). The purpose of focus groups is to produce a comfortable atmosphere of disclosure (Krueger \& Casey, 2015). Focus group methodology, although originated in other fields, is an increasingly popular, although underused, design for educational research (Cohen, Manion, \& Morrison, 2018; Wilson, 1997) and has been used in prior work in this field (e.g. Thornton et al., 2018). Four focus groups of Bangladesh college Heads of Department were organised, each comprising of the optimum number of 6 to 8 (Krueger \& Casey, 2015). Each focus group deliberately was of mixed gender, contained both public and private college staff and had a range of teaching subjects represented, ranging across political science, accounting, physics, economics and English. All participants had been teaching in a college for a minimum of ten years. The total number of participants was 26 , six of whom were female, and all were from colleges that were affiliated to the National University.

The focus group discussions took place at a branch campus of a Western university in South East Asia in 2018 where the participants were temporarily studying as part of a development programme for Bangladesh college staff. The opportunistic sample was gained from this cohort. Each participant could express themselves clearly in English, this was particularly important here as the discussions were to be held using English, not the mother tongue of the participants. The situ was useful as all the participants readily spoke freely about their role and challenges they faced; it is notable that all Heads of Department present in the programme volunteered to participate. Successful focus groups move beyond simply using verbal answering questions and may often seek to gain data through the use of a range of stimuli, including pictures, video and drawing tasks (Newby, 2014). Each focus group was initially 
split in half, creating smaller groups of threes or fours, with a task of producing three posters per smaller group; a diagram of the academic staffing structure in a typical Bangladesh college, and two 'word walls', one of the Head of Department role in a Bangladesh college and the other of the challenges they face. These posters were then used as foci for discussion in the focus group. Such techniques as drawing move the focus away from the moderator and, as Krueger \& Casey (2015) note, 'often the most valuable aspect of this exercise is in the discussion following the creation of the diagram' (Krueger \& Casey, 2015 p.55). All the focus groups were recorded, transcribed and emergent themes gained.

There are limitations on this work that stem from the size and type of sample and the use of focus groups. It is difficult to generalise from the sample here to the whole of Bangladesh as the sample is small and was opportunistic. However, it is notable that the data gained was remarkably similar in each focus group, indicating a pattern. In order to improve reliability a structure was given to the focus group discussion by the creation of the posters to a specific task and all groups were conducted by the same experienced moderator, the author (Morgan, 1997). This congruence of data, from different participants, offers support for credible findings (Stewart \& Shamdasani, 2014; Yin, 2015). Furthermore, the data appears to attune and cohere with other data sources (Litosseliti, 2003) within the literature creating a consensus of working in Bangladesh colleges providing reliability.

\section{Findings and Discussion}

In this section, the findings and discussion are presented together, each research question addressed in turn. In general, discussions did not show large differences between different subject heads and if the participants were from government or non-government colleges.

\section{The leadership and management structure in Bangladesh colleges}


All eight drawings of the organisational structure of a Bangladesh college by the participants were remarkably similar. The management structure in a Bangladesh college, irrespective if public or private, appears to be similar if not identical and is displayed as Figure 1. Although there was discussion and disagreement of the source of this structure, nonetheless participants agreed that they felt it was external to the college and not possible to change; the World Bank (World Bank, 2017) state that the academic structure of a college is the responsibility of the National University.

Figure 1 Organisational Structure of A Bangladesh College

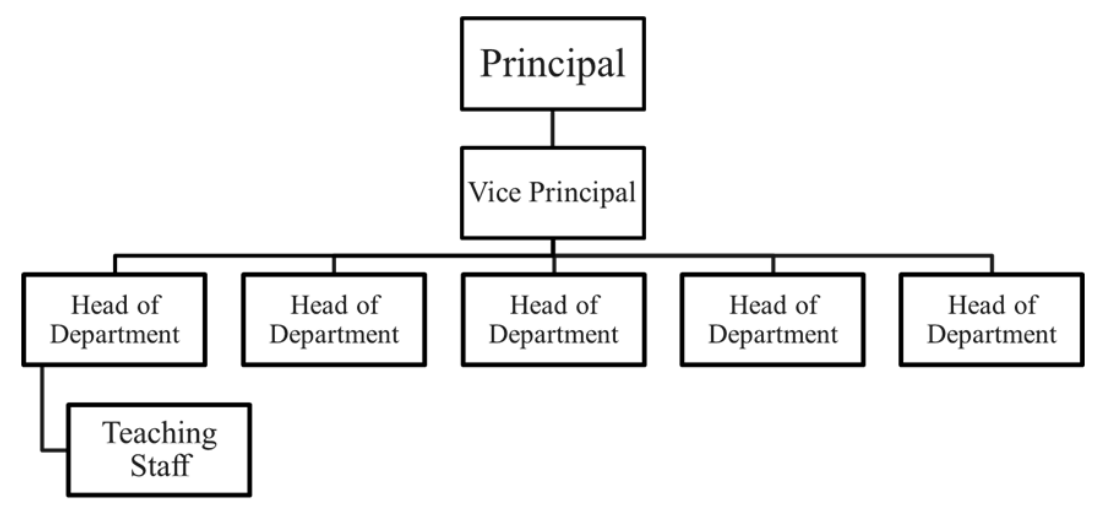

The participants believed that this structure was common practice in all colleges in Bangladesh. The structure is linear and very basic, with a principal at the top of a hierarchal pyramid and the Heads of Department below a vice principal, although some institutions did not have vice principal. This basic structure differs from many tertiary institutions in the West, there is no faculty system nor a diversity of management roles such as Deans, Associate Deans, Project Director etc. Universities in Bangladesh may have roles with titles that are familiar in the West, such as Vice Chancellor and Dean, however it appears that there may well be less of a range than in Western countries, and further work is warranted here. 


\section{The leadership and management progression routes for academic staff in a Bangladesh}

college

The literature may occasionally refer to Bangladesh college principals but little else in terms of management role titles. Although the National University is responsible for the staffing structure within all colleges in Bangladesh, both public and private, promotion progression is based around being a civil servant. This is also true within universities with specific minimum lengths of tenure stipulated for promotion. A significant difference in the roles though between university and college academic staff is the expectation of research and publishing in universities and this may be reflected in promotion criteria. The participants explained that all government teachers enter teaching through the civil service entrance exam. The civil service is divided into different groups or cadres, Participant 4 explains:

in government colleges we are all civil servants, we pass the very demanding entrance exam and are professionals under BCS technical/professional cadre. Successful completion of 5 years you become Assistant Professor. This is covered under the Bangladesh Civil Service (Examination for Promotion Rules) 1986. This notice comes from the Ministry (of Education). Then following that a further passage of time to Associate Professor and then full Professor status.

There was further discussion from the participants over non-government colleges and progression. The non-government college teachers who were participants were all in receipt of Monthly Pay Order pay subventions paid directly from the Ministry of Education, which, as participant 5, pointed out, 'makes us essentially the same, apart from we do not have associate or full professors in non-government colleges'. Once again they were aware of nongovernment colleges which were not in receipt of Monthly Pay Order subventions and did not offer the same pay nor status progression, corroborating the World Bank (2013) when it observes that such institutions 'may pay teachers very low salaries with limited benefits on an irregular pay schedule' (World Bank, 2013 p.79). The Monthly Pay Order system in Bangladesh is problematic. Although about half of the teachers in non-government colleges 
receive Monthly Pay Order subventions (World Bank, 2014) nonetheless there are a number of 'systemic loopholes' which 'often lead to misuse of Monthly Pay Order subventions' and that the 'structure allows for a chain of corruption' (World Bank, 2014 p.v). The issues surrounding Monthly Pay Order payments have created protest action by college academic staff including hunger strikes (Billah, 2019).

Bangladesh colleges have a linear career advancement with progression based on years in service. Following an initial training of four months, academic staff go through the route of Demonstrator (an unqualified position), Lecturer, Assistant Professor, Associate Professor and Professor in the case of government colleges, but only up to assistant professor in nongovernment colleges. Once again this is similar in Bangladesh universities, although private universities may offer the higher academic positions. To gain the Head of Department role a minimum grade of Associate Professor is required for government colleges, non-government colleges do not have the same restrictions. When a vacancy occurs, the promotion to Head of Department is based entirely on rank and longevity. It is seen as additional status and as recognition for service years but also part of what is expected professional practice. Table 1 summarises these positional posts. Participants spoke of 'duty', 'service' and 'recognition of loyalty'. They felt strongly about service in terms of their profession and to the country. The member of staff who has highest rank will be chosen, when more than one staff member is in that position then years of service will be the deciding factor. 
Table 1: Summary of Academic Posts in Bangladesh colleges

\begin{tabular}{|c|c|c|c|c|c|c|}
\hline \multirow[t]{2}{*}{ Time } & \multicolumn{3}{|c|}{ Government college } & \multicolumn{3}{|c|}{ Non-Government college } \\
\hline & Staffing titles & $\begin{array}{l}\text { Position } \\
\text { required } \\
\text { for Head of } \\
\text { Department }\end{array}$ & $\begin{array}{l}\text { Position } \\
\text { required for } \\
\text { Principal }\end{array}$ & Staffing titles & $\begin{array}{l}\text { Position } \\
\text { required } \\
\text { for Head of } \\
\text { Department }\end{array}$ & $\begin{array}{l}\text { Position } \\
\text { required } \\
\text { for } \\
\text { Principal }\end{array}$ \\
\hline \multirow{5}{*}{$\begin{array}{l}\text { Approx. } \\
15 \\
\text { years }\end{array}$} & Professor & & & & & \\
\hline & $\begin{array}{l}\text { Associate } \\
\text { Professor }\end{array}$ & & & & & \\
\hline & $\begin{array}{l}\text { Assistant } \\
\text { Professor }\end{array}$ & & & $\begin{array}{l}\text { Assistant } \\
\text { Professor }\end{array}$ & & \\
\hline & Lecturer & & & Lecturer & & \\
\hline & Demonstrator & & & Demonstrator & & \\
\hline
\end{tabular}

Greyed out areas are title/posts unavailable eg Associate Professor is the minimum for a government college Head of Department, although that title is unavailable in Non-Government colleges

An interesting note was the concern that the appointment was given directly by the college principal and not from the Ministry of Education and therefore the participants perception was that it did not have the status it deserved. The participants described the process of promotion to principal as one of passing a further examination to enter a talent pool from which principals were then selected. Whilst the participants were respectful of the authority of a principal position they were dismissive of the process, regarding that the selection was based on nepotism or political chicanery, 'the selection panel will have his (the successful principal) son or uncle or the party chairman on it' was a typical comment. This corresponds with some of the literature that refers to the politicisation of governance in the tertiary sector in Bangladesh (Monem \& Beniamin, 2010; Transparency International Bangladesh, 2016; World Bank, 2017) although the participants here referred to such practice as widespread and their response within the focus groups was frequently of laughter and derision of the process. Further work would need to be undertaken on this particular theme.

This organisational structure and career progression routes in colleges differ significantly from the available Western-based literature (although universities frequently have some of the titles 
available in the West). The leadership and management structures here are more simplistic and the automatic progression would not occur in Western tertiary education, which would perceive itself as based on a concept of meritocracy with its emphasis on open job advertisements, applications and a selection process often based on face-to-face interview for such a role as a head of department. These roles are often of a fixed term nature (Franken et al, 2015) whilst in Bangladesh the posts are permanent. In the West, progression from say assistant to associate professor would frequently be based on criteria that includes specific goals achieved like the publication of academic papers and would not be automatic. Western tertiary education systems are not controlled by government ministries, although they may well be legal constraints and fiscal ties to government, nonetheless there is greater autonomy for institutions.

\section{The Head of Department's role in a Bangladesh college}

The role of a Head of Department in a college is primarily one of paper-based administration. The posters, and subsequent discussions, all focused around the tasks such as timetabling classes, rooming and purchase of basic teaching materials. This was common across all participants irrespective of college or subject taught.

This emphasis on the 'running of the department' (participant 1) extended to departmental meetings, which focused on information giving and not on student learning. Participant 8, was frustrated by his experience of the prevailing culture, 'from my experience I can generally say that I have never discussed teaching and learning at these meetings, it is all who is teaching which class and in which room. Rooms, rooms is what we talk about'. This latter comment came following a moderator prompt about the Head of Department role and student learning as it had not occurred on posters.

There was no specific leadership preparation for the role, and little development following appointment. Participants said they had learnt the role 'shadowing' the previous incumbent. 
They were concerned about the lack of a job description and sought the creation of a guidebook to assistance them; a manual.

Key elements of the Head of Department role in the literature such as providing strategic vision (Bryman, 2007), staff performance reviews and the responsibility for their professional development (Franken, Penney, \& Branson, 2015) were absent from the participants' discussions. In particular there is little leadership element to their role, the word 'leadership', nor any associated words such as 'vision-building', 'influencing others' or 'values' were expressed by any participant within the posters or focus group discussions. This is somewhat surprising given the context of the where the discussions were held; during a training programme within which all the participants had successfully passed a module exploring leadership. Participant 2, comments on the title of the research project (Leadership in Bangladesh colleges) when signing the consent form are illuminating, 'why are we doing this? We are not the leaders, the principals are'; concepts around middle leadership clearly being absent.

\section{The challenges that face Heads of Department in a Bangladesh college}

Although there was a range of challenges offered by the participants, four overall themes emerged: staffing shortages; student politics; lack of training and role autonomy.

The students apply to the National University and the National University controls the roll of the college, this results in a significant problem with staffing and rooming classes. Every participant stated that there were too many students for their college, which made it challenging to room each session, and there may well be issues associated with the rapid growth of private colleges here that merits further exploration. This results in a shortage of teaching staff, particularly as the Ministry of Education in a government college makes additional 
appointments and consequently a time lag may occur to fill a vacancy. Participant 6 , comments were typical, 'daily I have to check that each class has a teacher, if not I need to get someone or take it myself', participant 14, elaborates stating 'our teachers have to teach more than they should because there are so many students and the rooms are too small so we run a class twice'. Approximately three quarters of the participants had staff vacancies in their department, in a government college this could take up to three years to fill with a permanent staff member, although temporary provision can be made. The World Bank concurs commenting that 'The inefficient process of recruiting teachers for government colleges has led to ....an extended period of vacancies and chronic teacher shortages' (World Bank, 2013 p.79).

The number of staff vacancies is exacerbated by staff absenteeism. There does not appear to be publically available data on staff and student attendance in colleges but student and staff attendance and punctuality is a significant issue in educational institutions in Bangladesh. Primary schools may have pupil absenteeism as high as 33 per cent and The World Bank state that 'various studies have reported that about 13-17 percent of teachers are absent..., and some 30 percent of teachers are late coming to school...[whilst in secondary schools] some 32 percent of teachers are late to school by more than 15 minutes and close to 50 percent of teachers are not in school at the beginning of a school day' (World Bank, 2013 p.77). There appears to be no such data for colleges; however, the participants all see it as a live issue, visiting classes in order to check that teachers are present. This is very similar to one participant in Parvin's (2019) study of leaders in a Bangladesh university, 'My management included assigning course teachers/examiners/supervisors, maintaining term calendar/class routine, taking exams, and preparing exam results. I also tried to make sure teachers are taking classes regularly through visiting classes physically' (Parvin, 2019 p.748). 
Challenging staff absenteeism and punctuality, along with any other areas of staff behaviour, was not seen as part of the Head of Department role. This differs from the extant literature which points to dealing with such issues as a major challenge for Heads of Department (Pepper \& Giles, 2015; Thornton et al., 2018). It did not occur in the discussions, but clarification was gained following a moderator prompt. The principal would deal with such indiscretions, though this may follow a request from a Head of Department.

The data in this study corroborates the literature when it points to higher education institutions in Bangladesh being political sites (Alam, Mishra, \& Shahjamal, 2014; Hossain \& Mohammad, 2015; Kabir \& Greenwood, 2017; Monem \& Beniamin, 2010). Participants refer to unannounced, seemingly random, disruption of classes by student political demonstrations. Each political party in Bangladesh has its own student wing, which is active on campus, although this appears less so in female only colleges. A Head of Department can be central to student complaints having potential power to pass and fail students. This cumulates in political activists' threats to ensure certain students pass. Participant 11 explained a scenario, 'I have a student come to me, political leader of a party, saying I have to pass a certain student. Now the student has not attended and is unlikely to pass. But I am told very clearly [he bangs his fist on the table and raises his voice to exemplify] he must pass. So what do I do?' When asked to clarify the potential consequence, he continued, 'this intimidation is clear to me, either physical violence or more likely he might say he knows chairman of the local party and this could affect my job'. This intimidation is real and is not seemingly uncommon.

The lack of Head of Department autonomy was a challenge for many of the participants. This included day-to-day running of the department with approval for many aspects required from the principal; even small purchases required a principal counter signature. They also felt their voice was unheard in college decisions and in particular in changes in the curriculum from the National University. The World Bank comment that 'Since the National University sets the 
curriculum centrally for colleges under its mandate and there is limited flexibility in attaining the curriculum objectives, colleges are constrained in innovating and improving the quality of

instruction independently' (World Bank, 2013 p.100). In this study participant 4, put this more succinctly, 'the National University is always changing what we have to teach but never ever asks us!' This lack of voice alienates Heads of Department, their role being seemingly limited to one of completing paper-based forms.

The challenges facing Heads of Department in a Bangladesh college appear to be different to the ones in the, predominately Western-based, literature. The role and the challenges it brings were very similar across subjects and types of colleges. There did not appear to be any specific gender issues arising in the data, however, the method of data collation, mixed gender focus groups, may not illicit this data and further work would need to be carried out, maybe in single sex interviews or focus groups.

\section{Conclusion}

This study explored middle managers in tertiary colleges in Bangladesh, where the majority of higher education students study. It sought to answer four research questions which emanated from the literature review being gaps in the extant literature. The first two questions explored leadership and management structures within the colleges and potential staff progression routes. The structures were found to be rigid and similar across different colleges including both government and non-government funded colleges. The structures were reported to basic and hierarchal with a principal at the top and each head of department directly below the. Staff progressed by longevity gaining the post of Head of Department by seniority when one was available. This is new knowledge to the field and further work need to be undertaken of equivalent roles in other countries. 
The other two research questions sought to discover the Head of Department's role in Bangladesh colleges and the challenges that it brings, once again there was no literature on this subject. The role appears to be predominately administrative although there are significant challenges. The challenges that Heads of Department face are significant; large staffing shortages, a highly politically charged culture that sometimes manifests itself in student intimidation and concerns over lack of pay. The participants here though were also concerned over their lack of voice, omissions from centralised decisions such as curriculum reform and seemingly no leadership role either within their own institution or representation on a national level.

The organisational structures, career progression, roles and challenges of Heads of Department in Bangladesh differ significantly from the extant literature, which is predominately Western based; there is a need to explore the experiences of higher education leaders globally. For example, in the literature a major concern in Western Higher Education Institution Heads of Department is dealing with awkward staff; the Bangladeshi counterparts defer this to their principal.

The challenges the Heads of Department face and the limited role they have, are systematic and systemic of higher education organisation in Bangladesh; their operational management task-focused role is systematic within a top down centralist education system, one that appears not to value devolved input. The restrictions facing such post holders are also systemic within this highly centralised system that replicates such roles at varying levels, a system that normalises functionalist and managerialist approaches to professional life.

The areas for further research include exploring such roles in universities in Bangladesh too as there appears to be some parallels in the work of Parvin (2019). There is a dearth of academic literature about university academic leadership and management in Bangladesh. Also, the 
nature of private ownership of colleges and universities, focusing on the role of the for-profit motive. The political aspects of governance and principal appointments is an area for further work too.

There may be hope in the World Bank funded College Education Development Project; such large-scale venture may well have the impact that is required to revitalise the National University and its affiliated colleges. The aims, and large funding associated with this project, may produce a system, and staff, that gives greater autonomy to its middle management, which in turn could develop their leadership potential. The leadership and management role of Heads of Department are crucial to higher education institutions' very function; such staff are at the heart of organisational corporeal. 


\section{References}

Alam, G. M., Mishra, P. K., \& Shahjamal, M. M. (2014). Quality assurance strategies for affiliated institutions of HE: a case study of the affiliates under National University of Bangladesh. Higher Education, 68 (2), 285-301.

Arif, M. Z. U., Rahman, M. I., Reza, S. M., \& Osman, A. R. (2013). A Comparative Study on Job Satisfaction among the Teachers of Affiliated Public and Private Colleges of National University of Bangladesh with Special Reference to Dhaka City. International Journal of Trade and Commerce, 2 (2), 410-424.

Asian Development Bank. (2014). Innovative Strategies in Higher Education for Accelerated Human Resource Development in South Asia. : Asian Development Bank avialable at https://www.adb.org/sites/default/files/publication/184418/innovative-strategies-highereducation-ban.pdf accessed 10th October 2018

Black, S. A. (2015). Qualities of effective leadership in higher education. Open Journal of Leadership, 4, 54-66

Bleiklie, I., Enders, J., Lepori, B., \& Musselin, C. (2011). New public management, network governance and the university as a changing professional organization. In T. Christensen \& P. Laegreid (Eds.), The Ashgate Research Companion to New Public Management (161-176). Aldershot: Ashgate

Bryman, A. (2007). Effective leadership in higher education: A literature review. Studies in Higher Education, 32(6), 693-710.

Clegg, S., \& McAuley, J. (2005). Conceptualising middle management in higher education: A multifaceted discourse. Journal of Higher Education Policy and Management, 27 (1), 19-34.

Cohen, L., Manion, L., \& Morrison, K. (2018). Research methods in education. Abingdon: Routledge.

Crosthwaite, C. (2018). Identifying the Role and Managerial Leadership Competencies of Postgraduate Heads of Departments. In Padró F., Erwee R., Harmes M., Harmes M., \& D. P. (Eds.), Postgraduate Education in Higher Education (pp. 1-22). Singapore: Springer.

Enders, J., \& Musselin, C. (2008). Back to the future? The academic professions in the 21st century. Higher education to $20301,125-150$.

Floyd, A. (2012). 'Turning Points' The Personal and Professional Circumstances That Lead Academics to Become Middle Managers. Educational Management Administration \& Leadership, 40 (2), 272-284

Floyd, A. (2016). Supporting academic middle managers in higher education: Do we care? Higher Education Policy, 29 (2), 167-183.

Floyd, A., \& Dimmock, C. (2011). 'Jugglers','copers' and 'strugglers': academics' perceptions of being a head of department in a post-1992 UK university and how it influences their future careers. Journal of Higher Education Policy and Management, 33 (4), 387-399.

Franken, M., Penney, D., \& Branson, C. (2015). Middle leaders' learning in a university context. Journal of Higher Education Policy and Management, 37 (2), 190-203.

Hallinger, P., \& Chen, J. (2015). Review of research on educational leadership and management in Asia: A comparative analysis of research topics and methods, 1995-2012. Educational Management Administration \& Leadership, 43 (1), 5-27.

Hossain, M. M., \& Mohammad, A. M. (2015). Higher Education Reform in Bangladesh: An Analysis. Workplace: A Journal for Academic Labor, 25, 64-68.

Ibrahim, M. S. (2012). Multidimensional Leadership Orienations and Lecturers Work Commitment: the mediation of Leadership Effectiveness among Malaysian Polytechnic Heads of Department. Asean Journal of Teaching and Learning in Higher Education (AJTLHE), 4 (2), 3350.

Islam, F. (2008). Some issues of higher education in Bangladesh: Analysis of demand, problems and trends. Prime University Journal, 2 (2) 137-152.

Kabir, A. H. (2012). Neoliberal hegemony and the ideological transformation of higher education in Bangladesh. Critical Literacy: Theories and Practices, 6 (2), 2-15. 
Kabir, A. H., \& Greenwood, J. (2017). Neoliberalism, Violence and Student Resistance in the Higher Education Sector in Bangladesh. Society and Culture in South Asia, 3 (1), 68-91.

Kitzinger, J. (1994). The methodology of focus groups: the importance of interaction between research participants. Sociology of health \& illness, 16(1), 103-121.

Krueger, R. A., \& Casey, M. A. (2015). Focus groups: A practical guide for applied research: London, UK: Sage

Litosseliti, L. (2003). Using focus groups in research. London: Continuum

Lumby, J. (2012). What do we know about leadership in higher education? Leadership Foundation for Higher Education. available at https://eprints.soton.ac.uk/388006/1/LFHE_review_paper_2012.pdf. accessed 10/1/19.

Monem, M., \& Beniamin, M. H. (2010). Higher Education in Bangladesh: Status, Issues and Prospects. Pakistan Journal of Social Sciences (PJSS), 30 (2), 293-305.

Morgan, D. L. (1997). Focus groups as qualitative research. Thousand Oaks, Calif. USA: Sage Newby, P. (2014). Research methods for education. Harlow, UK: Pearson.

Parvin, A. (2019). Leadership and management in quality assurance: insights from the context of Khulna University, Bangladesh. Higher Education 77 (4), 739-756.

Pepper, C., \& Giles, W. (2015). Leading in middle management in higher education. Management in Education, 29 (2), 46-52.

Pronay, B. (2011). Job satisfaction of non-government college teachers in Bangladesh. Journal of Education and Practice, 2(4), 87-91.

Rabbani, G., \& Chowdhury, S. (2014). Quality of higher education in Bangladesh: Governance framework and quality issues. Beykent University Journal of Social Sciences, 7 (1), 78-91.

Stewart, D. W., \& Shamdasani, P. N. (2014). Focus groups: Theory and practice. Thousand Oaks, USA: Sage.

Tahir, L., Abdullah, T., Ali, F., \& Daud, K. (2014). Academics transformational leadership: an investigation of heads of department leadership behaviours in Malaysian public universities. Educational Studies, 40 (5), 473-495.

Thornton, K., Walton, J., Wilson, M., \& Jones, L. (2018). Middle leadership roles in universities: Holy Grail or poisoned chalice. Journal of Higher Education Policy and Management, 40 (3), 208223.

Transparency International Bangladesh. (2016). Recruitment of Lecturers in Public Universities Governance Challenges and Ways Forward. Executive Summary available at https://www.tibangladesh.org/beta3/images/2016/Executive_summary_(English)_University_Recruitment _StudyFinal.pdf accessed 4th October 2018.

Wilson, V. (1997). Focus groups: a useful qualitative method for educational research? British Educational Research Journal, 23 (2), 209-224.

World Bank. (2013). Bangladesh Education Sector Review: Seeding Fertile Ground: Education That Works for Bangladesh. Report No. 80613-BD. Dhaka: World Bank.

World Bank. (2014). A Study on National University and Affiliated Colleges in Bangladesh: International Bank for Reconstruction and Development/The World Bank.

World Bank (2016). College Education Development Project. Available at http://projects.worldbank.org/P154577/?lang=en\&tab=overview accessed 10th March 2018

World Bank. (2017). SABER Country Report: Bangladesh Tertiary Education available at http://wbgfiles.worldbank.org/documents/hdn/ed/saber/supporting_doc/CountryReports/T ED/SABER_Tertiary_Bangladesh_CR2017_preliminary.pdf accessed 10th October 2018

Yin, R. K. (2015). Qualitative research from start to finish. New York Guilford Publications. 